\title{
Peningkatan Aktivitas dan hasil Belajar Biologi Melalui Problem Based Learning Pada Siswa Kelas XI MIPA 1 SMA Negeri 1 Tawangsari
}

\author{
Dita Nur Apsita ${ }^{1}$, Tri Wiharti ${ }^{2}$, Suwarto $^{3}$ \\ ${ }^{123}$ Program Studi Pendidikan Biologi, Universitas Veteran Bangun Nusantara Sukoharjo \\ Alamat email koresponden: nurapsita@ gmail.com \\ diterima: 10 Agustus 2019, disetujui: 15 Agustus 2019, dipublikasikan: 30 September 2019
}

\begin{abstract}
Abstrak
Penelitian ini bertujuan untuk meningkatkan aktivitas dan hasil belajar biologi melalui model Problem Based Learning pada siswa kelas XI MIPA 1 SMA Negeri 1 Tawangsari Tahun Pelajaran 2018/2019. Penelitian ini merupakan penelitian tindakan kelas yang terdiri dari 3 siklus. Setiap siklus terdiri dari perencanaan, tindakan, observasi, dan refleksi. Teknik pengumpulan data dengan menggunakan dokumentasi, tes dan lembar observasi. Data hasil belajar diambil dengan menggunakan post test, dan aktivitas belajar diambil melalui lembar observasi. Hasil penelitian menunjukkan bahwa pada kondisi awal dari 36 siswa yang mencapai ketuntasan adalah 14 siswa (40\%), siklus I terjadi peningkatan yaitu 18 siswa $(51 \%)$ mencapai ketuntasan, siklus II meningkat menjadi 25 siswa (70\%) mencapai ketuntasan, siklus III meningkat menjadi 30 siswa (84\%) mencapai ketuntasan. Untuk aktivitas belajar siklus I, penilaian aspek afektif yaitu $(47,22 \%)$ dan aspek psikomotorik yaitu $(44,44 \%)$ dengan kriteria rendah, siklus II penilaian aspek afektif meningkat menjadi $(69,44 \%)$ dan aspek psikomotorik $(63,88 \%)$ dengan kriteria sedang dan siklus III aktivitas belajar dalam penilaian aspek afektif mencapai $(83,33 \%)$ dan aspek psikomotorik $(80,55 \%)$ dengan kriteria tinggi. Berdasarkan hasil penelitian dapat disimpulkan bahwa Problem Based Learning dapat meningkatkan aktivitas dan hasil belajar siswa.
\end{abstract}

Kata Kunci: Aktivitas Belajar, Hasil Belajar, Problem Based Learning

\section{Improvement of Biology Learning Activities and Outcomes Through Problem- Based Learning in Class XI 1 MIPA 1 Senior High School 1 Tawangsari}

\author{
Dita Nur Apsita $^{1}{ }^{*}$, Tri Wiharti ${ }^{2}$, Suwarto $^{3}$ \\ ${ }^{123}$ Biology Education Department, Universitas Veteran Bangun Nusantara Sukoharjo \\ Email: ${ }^{\text {nurapsita@ gmail.com }}$

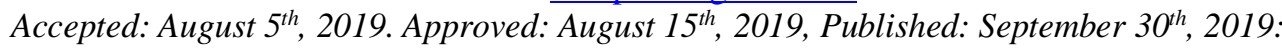

\begin{abstract}
This study aims to improve the activities and learning outcomes of biology through the Model of Problem Based Learning (PBL) in class XI MIPA 1 SMA Negeri 1 Tawangsari 2018/2019 Academic Year. This research is a class action research consisting of 3 cycles. Each cycle consists of planning, action, observation, and reflection. The technique of collecting data using documentation, tests and observation sheets. Learning outcomes data were taken using a post test, and learning activities were taken through observation sheets. The results showed that in the initial condition of 36 students who achieved completeness were 14 students (40\%), cycle I had increased 18 students (51\%) had completed, cycle II had increased to 25 students (70\%) had completed, cycle III had increased to 30 students (84\%) achieved mastery. For the learning activities of the first cycle, namely Affiliation aspects (47.22\%) and psychomotor aspects (44.44\%) with low criteria, cycle II Assessment of affective aspects increased to (69.44\%) and psychomotor aspects (63.88) )\%) with moderate criteria and cycle III learning activities in the affective aspects reached (83.33\%) and psychomotor aspects $(80.55 \%)$ with high criteria. Based on the results of the study it can be concluded that PBL can improve the activities and learning outcomes of students.
\end{abstract}

Keywords: Learning Activities, Learning Outcomes, Problem Based Learning 


\section{PENDAHULUAN}

Pendidikan merupakan faktor yang sangat penting dalam kehidupan manusia dan tidak dapat dipisahkan antara satu dengan lainnya. Dilihat dari segi keberadaanya, maka dapat dikatakan bahwa pendidikan ada sejak adanya manusia. Pendidikan sebagai salah satu sector yang mendapat perhatian bagi kemajuan suatu Negara, khususnya dalam era globalisasi. Melalui pendidikan diharapkan manusia untuk dapat kreatif dalam mengambil langkah antisipatif terhadap keadaan dan masalah yang muncul akibat globalisasi tersebut. Pengaruh globalisasi ini akan berdampak keseluruh Negara, oleh karena itu seluruh Negara harus betul-betul siap dalam menghadapi segala tantangan yang semakin berat (Anita, 2012:48).

Belajar adalah suatu proses usaha yang dilakukan oleh seseorang untuk memperoleh suatu perubahan tingkah yang baru secara keseluruhan, sebagai hasil pengalamannya sendiri dalam interaksi dengan lingkungan. Perubahan tingkah laku dalam proses belajar cirinya sebagai berikut: perubahan terjadi secara sadar, perubahan dalam belajar bersifat kontinu dan fungsional, perubahan dalam belajar bersifat positif dan aktif, perubahan dalam belajar bukan bersifat sementara, perubahan dalam belajar bertujuan atau terarah, perubahan dalam belajar mencakup seluruh aspek tingkah laku (Slameto 2010:2)

Kriteria Ketuntasan Minimal (KKM) yang ditetapkan oleh SMA N 1 Tawangsari pada mata pelajaran biologi kelas XI yaitu 75. Berdasarkan nilai ulangan harian hasil belajar diperoleh data sebagai berikut: kelas XI MIPA 2 ketuntasan mencapai 78\%, XI MIPA 3 mencapai 80\%, XI MIPA 4 mencapai $75 \%$, XI MIPA 5 mencapai 80\%, XI MIPA 6 mencapai 83\%, dan terakhir kelasXI IPA 1 hanya mencapai $40 \%$ yang tergolong masih rendah jika dibandingkan kelas yang lain, dilihat dari nilai ulangan siswa yang memperoleh nilai di atas KKM yaitu 14siswa. Dengan jumlah kelas XI IPA 1 keseluruhan 36 siswa. Hal ini dilihat dari aktivitas dan hasil belajar siswa dalam pembelajaran biologi.

Proses pembelajaran dikelas Xl MIPA 1 diarahkan kepada kemampuan siswa untuk menghafal informasi. Di kelas guru masih sebagai sumber utama pengetahuan, kemudian ceramah masih mnjadi pilihan utama dalam menyampaikan pelajaran.Akibatnya guru lebih berperan dominan di dalam kelas (Teacher Centered). Siswa seringkali tidak mampu mencapai tujuan belajarnya atau tidak memperoleh perubahan tingkah laku sebagaimana yang diharapkan.Aktivitas guru yang lebih dominan daripada siswa, mengakibatkan siswa hanya menghafal ilmu pengetahuan yang di sampaikan guru, bukan memahaminya. Proses belajar mengajar menjadi sesuatu yang membosankan dan tak menyenangkan. Hal itu menunjukkan bahwa siswa mengalami kesulitan belajar dalam mencapai hasil belajar. Sehingga banyak pula siswa yang mengalami kesulitan hingga menimbulkan masalah bagi perkembangan pribadinya.

Gambaran permasalahan diatas menunjukkan bahwa pembelajaran Biologi di kelas XI MIPA 1 SMA Negeri 1 Tawangsari masih rendah dibandingkan kelas yang lain. Dengan demikian proses pembelajaran akan lebih aktif jika guru dapat memberikan metode yang tepat bagi siswa. Dengan menggunakan metode belajar aktif semua siswa bisa terlibat dalam kegiatan pembelajaran, dansiswa dapat melakukan sebagian besar kegiatan selama proses pembelajaran. Belajar aktif merupakan langkah cepat, menyenangkan, mendukung dan menarik hati dalam belajar. Proses belajar aktif berpusat pada siswa, selama proses pembelajaran yang paling penting siswa dapat memecahkan masalah sendiri, menemukan contoh-contoh, 
mencoba keterampilan baru, dan melaksanakan tugas tergantung pada pengetahuan yang telah mereka miliki atau yang akan dicapai.

Ada banyak metode dalam pembelajaran kooperatif learning, dimana setiap metode memiliki kekurangan dan kelebihannya masing-masing. Metode Problem Based Learning merupakan salah satu metode dalam pembelajaran kooperatif yang bertujuan merangsang peserta didik untuk belajar mengembangkan daya pikir, daya inisiatif, dan kreatifitas melalui berbagai permasalahan nyata dalam kehidupan sehari-hari yang berkaitan dengan materi pelajaran Biologi di Sekolah.

Problem Based Leaarning (PBL) atau Pembelajaran Berbasis Masalah (PMB) adalah model pembelajaran yang bercirikan adanya belajar berpikir kritis dan ketrampilan memecahkan masalah serta memperoleh pengetahuan (Duch,1995).

Finkle dan Trop (1995) menyatakan bahwa PBM merupakan perkembangan kurikulum dan sistem pengajaran yang mengembangkan secara simultan strategi pemecahan masalah dan dasar-dasar pengetahuan dan ketrampilan dengan menempatkan para peserta didik dalam peran aktif sebagai pemecah permasalahan sehari-hari yang tidak terstruktur dengan baik (Aris Shoimin, 2014:130).

Dari masalah yang muncul tersebut diharapkan dapat dipecahkan, sehingga keberhasilan dalam proses pembelajaran di sekolah dapat tercapai hingga $75 \%$ hasil pembelajaran mampu mencapai nilai KKM yang telah di tentukan. Berdasarkan uraian di atas maka peneliti akan melakukan penelitian yang berjudul : Peningkatkan Aktivitas dan Hasil Belajar Biologi Melalui Pembelajaran Problem Based Learning Pada Siswa Kelas XI MIPA 1 SMA Negeri 1 Tawangsari Tahun Pelajaran 2018/2019.

Tujuan Penelitian ini terdiri dari tujuan umum dan tujuan khusus. Tujuan umum yaitu untuk meningkatkan aktivitas dan hasil belajar Biologi pada siswa. Sedangkan tujuan khusus yaitu :untuk meningkatkan aktivitas belajar Biologi pada siswa kelas XI MIPA 1 SMA Negeri 1 Tawangsari tahun pelajaran 2018/2019 dengan menerapkan model pembelajaran Problem Based Learning sehingga proses pembelajaran yang aktif, inovatif, menyenangkan, dan pada akhirnya dapat mencapai hasil pembelajaran yang tuntas, untuk meningkatkan hasil belajar Biologi pada siswa kelas XI MIPA 1 SMA Negeri 1 Tawangsari tahun pelajaran 2018/2019 dengan menerapkan model pembelajaran Problem Based Learning sehingga proses pembelajaran yang aktif, inovatif, menyenangkan, dan pada akhirnya dapat mencapai hasil pembelajaran yang tuntas.

Hasil penelitian ini diharapkan dapat memberikan manfaat secara teoritis dan praktis. Manfaat teoritis dari penelitian ini yaitu: menambah informasi tentang efektifitas model pembelajaran Problem Based Learning terhadap aktivitas dan hasil belajar siswa. Manfaat Praktis dalam penelitian ini yaitu, bagi siswa : meningkatkan keaktifan siswa dalam pembelajaran biologi dan meningkatkan hasil belajar siswa, bagi guru : sebagai bahan pertimbangan dalam pemilihan model dan pendekatan pembelajaran untuk meningkatkan aktivitas dan hasil belajar biologi siswa, bagi sekolah : hasil penelitian ini dapat memberikan sumbangan yang baik bagi sekolah dalam rangka memperbaiki dan meningkatkan mutu sekolah,

bagi penelitian lain: dapat menambah pengetahuan dalam membekali diri sebagai calon guru yang memperoleh pengalaman penelitian secara ilmiah agar dapat dijadikan bekal sebagai guru dalam mengajar pembelajaran Biologi dengan menggunakan model pembelajaran Problem Based Learning. 


\section{METODE}

Jenis Penelitian ini adalah Penelitian Tindakan Kelas (PTK). Kegiatan penelitian dilaksanakan pada semester genap pada minggu ke empat bulan April sampai minggu pertama bulan Junipada siswa kelas XI MIPA 1 SMA Negeri 1 Tawangsari, tahun pelajaran 2018/2019 dengan jumlah siswa 36 yaitu 25 perempuan dan 11 lakilaki.

Sumber data pada penelitian ini yaitu aktivitas belajar siswa diperoleh dari lembar observasi pada proses pembelajaran dan hasil belajar kognitif dari post test pada proses pembelajaran. Prodsedur pengumpulan data pada penelitian ini yaitu dengan menggunakan dokumentasi, post test dan lembar observasi. Instrumen pada penelitian ini berupa Silabus, RPP (Rencana Pelaksanaan Pembelajaran), lembar observasi aktivitas siswa yaitu aspek afektif (sikap) dan psikomotorik (ketrampilan), dan soal post test (18 butri pilihan ganda). Tes juga digunakan dalam mengembangkan tindakan pada setisp siklus dalam penelitian. Dalam penelitian ini terdapat 3 uji instrumen tes yaitu: tingkat kesukaran butir, daya beda butir dan reliabilitas. Teknik analisis data yang digunakan dalam penelitian ini adalah deskriptif komparatif yaitu membandingkan hasil penelitian dari siklus I, siklus II, dan siklus III. Indikator keberhasilan pada penelitian ini adalah 75\% (18 siswa yang tuntas KKM) baik dari aktivitas siswa aspek afektif (sikap) dan pisikomotorik (ketrampilan) juga hasil belajar kognitif siswa.

Instrumen penelitian ini berupa: Silabus, RPP ( Rencana Pelaksanaan Pembelajaran), Lembar Kerja Siswa, soal tes pilihan ganda dan lembar observasi. Penelitian tindakan kelas ini terdiri dari 3 siklus penelitian, dimana dalam satu siklus tindakan meliputi perencaan tindakan (planning), pelaksaan tindakan (acting), pengamatan (observing), dan refleksi (reflecting). Berikut adalah skema penelitian tindakan kelas:

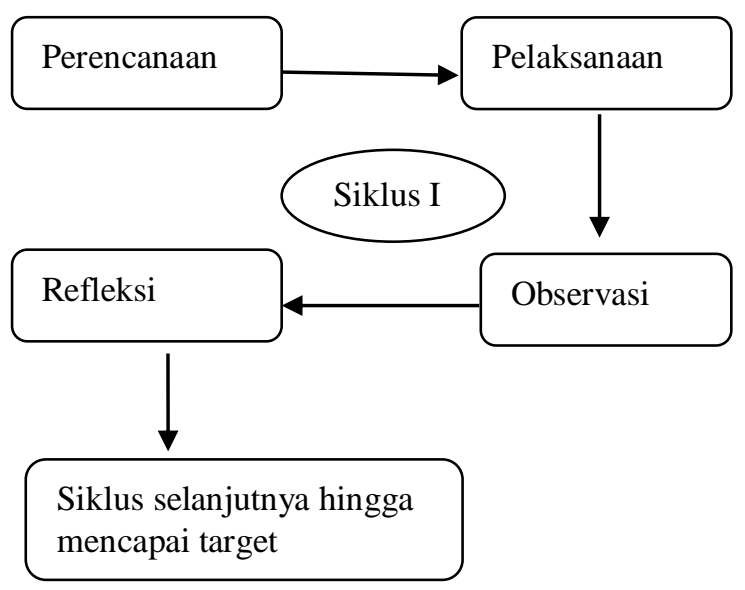

Gambar 1. Skema Penelitian Tindakan Kelas

\section{HASIL DAN PEMBAHASAN}

Penelitian Tindakan Kelas ini dilaksanakan di SMA Negeri 1 Tawangsari pada bulan Mei 2019.

\section{Siklus I}

Siklus I dilaksanakan dalam 2 kali pertemuan dengan alokasi waktu 4 jam pelajaran (4 x 45 menit) yaitu pada hari Kamis-Jumat tanggal 2 Mei - 3 Mei 2019 pada jam ke 9-10 dan jam ke 6-7. Proses pembelajaran dilakukan oleh guru biologi dan peneliti menggunakan satu observer sebagai pengamat dalam proses pembelajaran.

Dalam Tindakan Siklus I ini, sesuai dengan tahapan model Problem Based Learning $(P B L)$ yaitu terdapat 5 tahapan: Pertemuan pertama dengan waktu 2 jam (2x45 menit) pada awal pembelajaran, guru menjelaskan tujuan pembelajaran, menyampaikan garis besar tentang apa yang dilakukan siswa untuk menyelesaikan pembelajaran, kemudian guru memberi pertanyaan tentang suatu masalah yang berkaitan dengan materi pembelajaran, selanjutntnya guru menayangkan video tentang struktur jaringan penyusun organ reproduksi dan fungsinya. Pada tahap kedua mengorganisasi siswa untuk belajar : siswa 
diminta untuk membentuk kelompok 6 orang setiap kelompoknya, guru memberikan LKS (Lembar Kerja Siswa) dengan eksperimen sederhana untuk dikerjakan secara bersama dalam kelompoknya. Pada tahap ketiga yaitu membimbing penyelidikan maupun kelompok : siswa melakukan sesuai dengan petunjuk kerja sesuai dengan LKS (Lembar Kerja Siswa), siswa memecahkan suatu masalah yang ada di LKS tersebut bersama kelompoknya dengan menggunakan sumber pengetahuan berupa buku dari perpustakaan, siswa mengumpulkan data yang relevan dan mendiskusikan hasil diskusi mereka, guru membimbing siswa ketika siswa masih kesulitan dalam mengerjakan LKS (Lembar Kerja Siswa). Pada pertemuan kedua dengan waktu 2 jam (90 menit), pada tahapan ini melaksanakan tahapan keempat yaitu siswa mempresentasikan hasil diskusi mereka, siswa saling melakukan tanya jawab, setelah presentasi selesai siswa mengerjakan soal post test dengan wakti 15 menit. Selanjutnya melaksanakan tahap kelima yaitu siswa membuat kesimpulan pembelajaran.

\section{Siklus II}

Siklus II dilaksanakan dalam 2 kali pertemuan yaitu pada hari kamis-jumat pada tanggal 9-10 Mei 2019 alokasi waktu 4 jam pelajaran (4 x 45 menit) pada jam ke 9-10 dan jam ke 6-7. Pelaksanakan dilakukan oleh guru mata pelajaran biologi Rudy Sutomo, S.Pd. dan satu observer sebagai pengamat berlangsungnya pembelajaran.

Tindakan dalam siklus II, sesuai dengan tahapan model Problem Based Learning $(P B L)$, Pada tahap pertama orientasi siswa pada masalah : pertemuan pertama dengan waktu 2 jam ( $2 \times 45$ menit) pada awal pembelajaram, guru menjelaskan tujuan pembelajaran, menyampaikan garis besar tentang apa yang dilakukan siswa untuk menyelesaikan pembelajaran,kemudian guru memberi pertanyaan tentang suatu masalah yang berkaitan dengan materi pembelajaran, siswa menjawab pernyataan dari guru, selanjutnya guru menayangkan video tentang Proses pembentukan Sel Kelamin (Spermatogenesis dan Oogenesis) dan video tentang Ovulasi dan Menstruasi. Pada tahap kedua mengorganisasi siswa untuk belajar : siswa diminta untuk membentuk kelompok 6 orang setiap kelompoknya, guru memberikan LKS (Lembar Kerja Siswa) dengan eksperimen sederhana untuk dikerjakan secara bersama dalam kelompoknya. Pada tahap ketiga yaitu membimbing penyelidikan maupun kelompok : siswa melakukan sesuai dengan petunjuk kerja sesuai dengan LKS (Lembar Kerja Siswa), siswa diminta untuk memecahkan masalah yang di LKS tersebut dengan menggunakan sumber pengetahuan berupa wawancara, siswa mengumpulkan data yang relevan dan mendiskusikan hasil diskusi mereka, guru membimbing siswa ketika siswa masih kesulitan dalam mengerjakan LKS (Lembar Kerja Siswa). Pada pertemuan kedua dengan waktu 2 jam (90 menit), pada tahapan ini melaksanakan tahapan keempat yaitu : siswa mempresentasikan hasil diskusi, setelah presentasi selesai siswa mengerjakan soal post test dengan wakti 15 menit. Selanjutnya siswa melaksanakan tahap kelima yaitu:siswa membuat kesimpulan pembelajaran.

\section{Siklus III}

Siklus III dilaksanakan dalam 2 kali pertemuan dengan alokasi waktu 4 jam pelajaran (4 x 45 menit) yaitu pada hari Kamis-Jumat tanggal 16-17 Mei 2019 pada jam ke 9-10 dan jam ke 6-7. Pelaksanaan dilakukan oleh guru mata pelajaran biologi dengan satu observer yang mengamati jalannya pembelajaran.

Tindakan siklus III ini, sesuai dengan tahapan model Problem Based Learning $(P B L)$. yaitu terdapat 5 tahapan Pada tahap pertama orientasi siswa pada masalah : 
pertemuan pertama dengan waktu 2 jam (2x45 menit) pada awal pembelajaram, guru menjelaskan tujuan pembelajaran, menyampaikan garis besar tentang apa yang dilakukan siswa untuk menyelesaikan pembelajaran, kemudian guru memberi pertanyaan tentang suatu masalah yang berkaitan dengan materi pembelajaran, siswa menjawab pertanyaan dari guru, selanjutnya guru menayangkan video tentang proses pembentukan janin. Pada tahap kedua mengorganisasi siswa untuk belajar : siswa diminta untuk membentuk kelompok 6 orang setiap kelompoknya, guru memberikan LKS (Lembar Kerja Siswa) dengan eksperimen sederhana untuk dikerjakan secara bersama dalam kelompoknya. Pada tahap ketiga yaitu membimbing penyelidikan maupun kelompok : siswa melakukan sesuai dengan petunjuk kerja sesuai dengan LKS (Lembar Kerja Siswa), siswa diminta untuk memecahkan soal LKS tersebut dengan menggunakan sumber pengetahuan berupa internet, siswa mengumpulkan data yang relevan dan mendiskusikan hasil diskusi mereka, guru membimbing siswa ketika siswa masih kesulitan dalam mengerjakan LKS (Lembar Kerja Siswa). Pada pertemuan kedua dengan waktu 2 jam (90 menit), pada tahapan ini melaksanakan tahapan keempat yaitu mengembangkan hasil diskusi pada tahap keempat yaitu : siswa mempresentasikan hasil diskusi mereka, siswa melakukan tanya-jawab, setelah presentasi selesai siswa mengerjakan soal post test dengan wakti 15 menit. Selanjutnya siswa melaksanakan tahap terakhir yaitu siswa membuat kesimpulan pembelajaran.

Berdasarkan data hasil penilaian aspek afektif dari pelaksanaan pembelajaran dari siklus ke siklus yang lain mengalami peningkatan. Pada siklus I penilaian terhadap aspek afektif siswa 47,22\% , penilaian siklus II $69,44 \%$ dan penilaian pada siklus III sebanyak 83,33\% .

Peningkatan ketuntasan dari siklus I sampai siklus III, dapat dilihat pada gambar 2 :

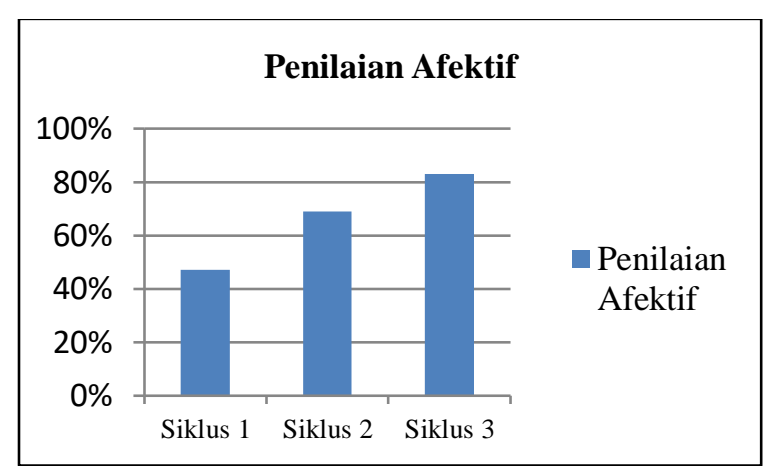

Gambar 2. Hasil belajar afektif

Hasil penilaian dari segi kognitif selalu mengalami peningkatan di setiap siklus. Pada siklus I 51\% (18 siswa). Pada siklus II $70 \%$ (25siswa). Pada siklus III $81 \%$ (29 siswa). Suatu kelas disebut telah mencapai ketuntasan klasikal $\geq 75 \%$. Peningkatan ketuntasan dari siklus I sampai siklus III, dapat dilihat pada gambar 3.

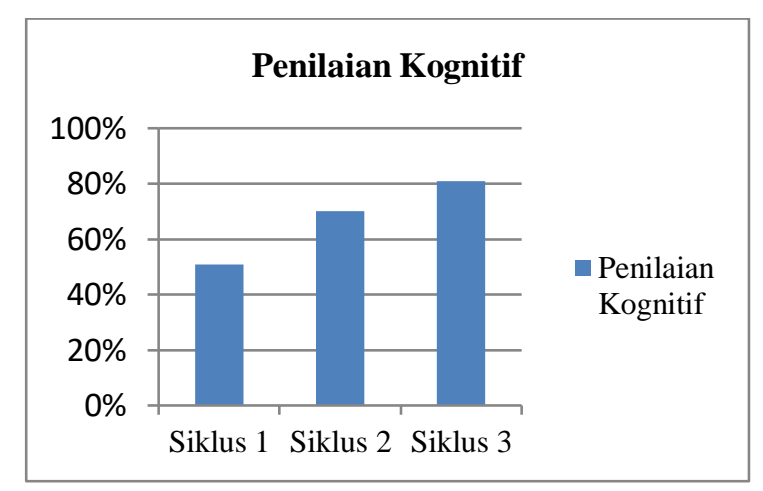

Gambar 3. Hasil belajar kognitif

Penilaian aspek psikomotorik dari pelaksanaan pembelajaran dari siklus ke siklus yang lain mengalami peningkatan. Pada siklus I penilaian terhadap aspek psikomotorik siswa $44,44 \%$, penilaian siklus II $63,88 \%$ dan penilaian pada siklus III sebanyak $80,55 \%$. 
Peningkatan ketuntasan dari siklus I sampai siklus III, dapat dilihat pada gambar 4 :

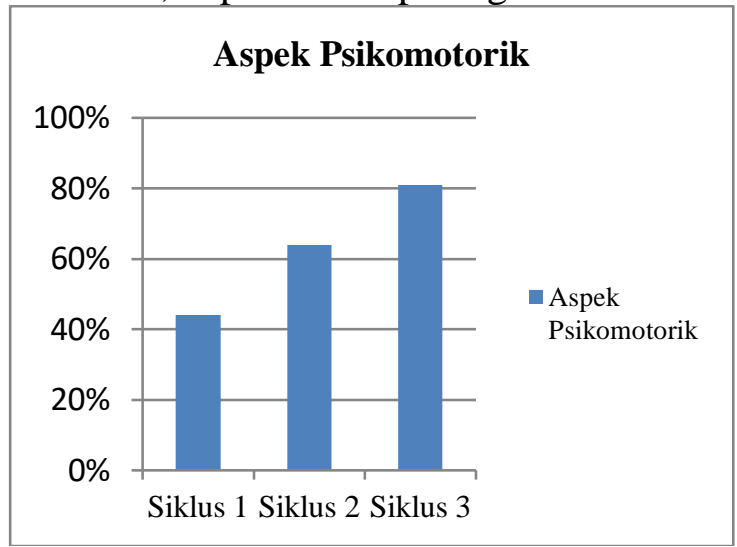

Gambar 4. Hasil belajar psikomotorik
Berdasarkan data hasil penelitian tentang penerapan model pembelajaran Problem Based Learning (PBL) yang dilaksanakan melalui tiga siklus tindakan, maka terlihat ada peningkatan diberbagai aspek. Dari peningkatan tersebut dapat dilihat dengan tabel dibawah ini :

Tabel 1. Perbandingan Hasil Belajar Biologi Siswa

\begin{tabular}{llllll}
\hline No & \multicolumn{1}{c}{ Keterangan Tindakan } & \multicolumn{1}{c}{$\begin{array}{c}\text { Kondisi } \\
\text { Awal }\end{array}$} & \multicolumn{1}{c}{ Siklus I } & Siklus II & Siklus III \\
& & & & \\
\hline 1. & Observasi Aspek Afektif & $41,66 \%$ & $47,22 \%$ & $69,44 \%$ & $83,33 \%$ \\
2. & Aspek Kognitif & $40 \%$ & $51 \%$ & $70 \%$ & $81 \%$ \\
3. Aspek & $\begin{array}{l}\text { Observasi } \\
\text { Psikomotorik }\end{array}$ & & $46,11 \%$ & $63,44 \%$ & $80,55 \%$ \\
\hline
\end{tabular}

Berdasarkan tabel 1 menunjukan bahwa, terjadi peningkatan aktivitas dan hasil belajar siswa dilihat dari sebelum di beri tindakan (kondisi awal) samapai di beri tindakan (Siklus I, Siklus II, dan Siklus III).

Berdasarkan hasil tersebut maka dapat dikatakan bahwa penerapan model pembelajaran Problem Based Learning $(P B L)$ dapat meningkatkan aktivitas belajar siswa sehingga hasil tersebut mempengaruhi hasil belajar siswa dimana hasil belajar siswa juga ikut meningkat. Hal ini dibuktikan dengan aktivitas belajar siswa yang terus meningkat disetiap siklusnya, nilai rata-rata siswa yang mengalami peningkatan dan ketuntasan klasikal yang terus mengalami peningkatan disetiap siklusnya dibandingkan sebelum menerapkan model pembelajaran Problem Based Learning (PBL). Dengan demikian dari pembahasan dan data-data yang disajikan, hasil belajar siswa diukur dari segi kognitif, afektif dan psikomotorik.

Hal ini sesuai dengan pendapat (M. Nurtanto\& Sofyan, H 2015:75) yang menjelaskan bahwa hasil belajar merupakan hasil yang diperoleh siswa setelah siswa tersebut melakukan proses belajar yang melibatkan ranah kognitif, afektif dan psikomotor yang diwujudkan dalam bentuk skor atau angka setelah mengikuti tes.

Melalui model pembelajaran Problem Based Learning (PBL) ini dapat membantu siswa mengembangkan ilmunya dengan mencari informasi, pada saat siswa berdiskusi mereka bertanggung jawab terhadap penyelesaian masalah. Hal ini sesuai dengan pernyataan, strategi pembelajaran dan model-model pendidikan yang bersifat bebas dan egaliter akan mendukung perkembangan aspek aspek afektif. Hal itu hanya dapat dicapai lewat proses pendidikan bebas dan metode 
pembelajaran aksi dialogikal (diskusi, tanya jawab, dan debat), keaktifan siswa menjadi unsur yang mata penting dalam menentukan kesuksesan belajar (Asry Budiningsih. C, 2009). Pendapat tersebut juga didukung oleh pendapat Aris Sohimin (2013:132), bahwa model pembelajaran Problem Based Learning mempunyai kelebihan: 1)Siswa didorong untuk memiliki kemampuan memecahkan masalah dalam situasi nyata, 2) Siswa memiliki kemampuan membangun pengetahuannya sendiri melalui aktivitas belajar, 3)Pembelajaran berfokus pada masalah sehingga materi yang tidak ada hubungannya tidak perlu dipelajari oleh siswa. Hal ini mengurangi beban siswa dengan menghafal atau menyimpan informasi, 4) Terjadi aktivitas ilmiah pada siswa melalui kerja kelompok, 5) Siswa terbiasa menggunakan sumber-sumber pengetahuan, baik dari perpustakaan, internet, wawancara dan observasi.

Dengan demikian dari pembahasan dan data-data yang disajikan, maka dapat disimpulkan bahwa model Problem Based Learning dapat meningkatkan aktivitas dan hasil belajar biologi siswa kelas XI MIPA 1 SMA Negeri 1 Tawangsari. Hal ini sesuai dengan penelitian Dewi, Akbari dan Nugroho (2019) menyatakan bahwa Problem Based Learning dapat meningkatkan aktivitas dan hasil belajar siswa, memperbaiki dan meningkatkan kualitas proses pembelajaran, meningkatkan partisipasi siswa.

Penelitian dari Wulansari, Hanik dan Nugroho (2019) pada kelas X SMA Negeri 1 Tawangsari menjelaskan bahwa model Problem Based Learning disertai mind mapping dapat meningkatkan hasil belajar biologi siswa dari segi, kognitif, afektif (sikap) dan psikomotorik (ketrampilan).

\section{KESIMPULAN DAN SARAN}

Berdasarkan kegiatan penelitian tindakan kelas yang dilakukan di SMA Negeri 1 Tawangsari Tahun pelajaran 2018/2019, maka dapat diambil kesimpulan bahwa "Melalui penerapan model pembelajaran Problem Based Learning dapat meningkatkan aktivitas dan hasil belajar siswa pada kelas XI MIPA 1 SMA Negeri 1 Tawangsari Tahun Pelajaran 2018/2019”.

Pada pembelajaran Problem Based Learning diharapkan lebih kreatif, inovatif dan menggunakan Problem Based Learning $(P B L)$ sesuai dengan materi pelajara, sehingga tujuan pembelajaran dapat tercapai.

\section{UCAPAN TERIMAKASIH}

Penelitian ini dapat selesai dengan baik karena bantuan dari berbagai pihak. Oleh karena itu penulis mengucapkan terimakasih kepada SMA Negeri 1 Tawangsari, serta siswa kelas XI MIPA 1 SMA Negeri 1 Tawangsari tahun Pelajaran 2018/2019.

\section{DAFTAR PUSTAKA}

C, Asri Budiningsih. (2009). Mengembangkan nilainilai afektif dalam pembelajaran. Journal Yogyakarta: KTP-FIP. Universitas Negeri Yogyakarta.

Dewi, E. H. P., Akbari, S., \& Nugroho, A. A. (2019). Peningkatan Aktivitas dan Hasil Belajar Biologi melalui Model Problem Based Learning (PBL) pada Materi Pencemaran Lingkungan Siswa Kelas X SMA Negeri 1 Jatisrono. Journal of Biology Learning, l(1).

Nurjanah, Anita. (2012). Pendidikan dan Faktorfaktornya .Yogyakarta: Pustaka Pelajar.

Nurtanto, M. \&Sofyan, H. (2015). Implementasi Problem Based Learning untuk meningkatkan hasil belajar kognitif, psikomotorik dan afektif siswa SMK. Jurnal Pendidikan Vokasi. PTK PPS Universitas Negeri Yogyakarta.

Slameto. (2010). Belajar dan Faktor-Faktor yang Mempengaruhinya. Jakarta: Rineka Cipta. 
Sohimin, Aris. (2014). Model Pembelajaran Inovatif Dalam Kurikulum 2013.Yogyakarta: ARRUZZ MEDIA.

Wulansari, B., Hanik, N. R., \& Nugroho, A. A. (2019). Penerapan Model Problem Based Learning (PBL) disertai Mind Mapping untuk Meningkatkan Hasil Belajar pada Siswa Kelas X SMA Negeri 1 Tawangsari. Journal of Biology Learning, I(1). 